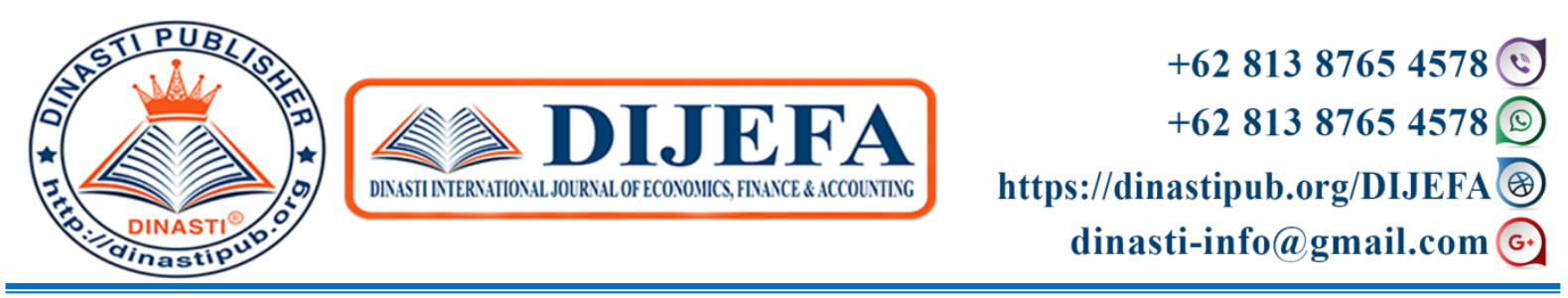

\title{
BUSINESS DEVELOPMENT STRATEGY WITH CANVAS MODEL BUSINESS APPROACH IN CV. HAKHENBIK
}

Iqbal Kamaluddin ${ }^{1}$

${ }^{1)}$ University of Mercu Buana, Jakarta, Indonesia

ARTICLE INFORMATION

Received: $22^{\text {nd }}$ May 2020

Revised: $19^{\text {th }}$ June 2020

Issued: $6^{\text {th }}$ August 2020

Corresponding author: Iqbal

E-mail:

iqbalkamaluddin88@gmail.com

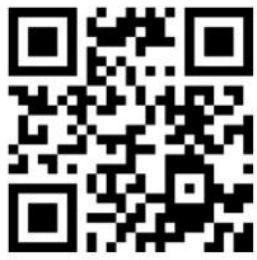

DOI: 10.38035/DIJEFA
Abstract: CV. Hakhenbik is a company engaged in the field of furniture and equipment of the school with its production material made from solid wood that has durable strength, and not easily damaged and has a high selling price. On this research author uses qualitative descriptive method that is by using the business model Business model Canvas (BMC), then evaluated using a SWOT analysis in every Business model Canvas (BMC) block on CV. Hakhenbik. The most powerful element in the Business Model Canvas is the Key Partnership, sis the value propositions. The elements that still lack are Customer Relationships and the next is Key Resources. Be rbased on SWOT analysis, CV. Hakhenbik is advised to improve on the element of customer relationshipsThis is because the important factor in running the business is to maintain good relations with the customer, one way to maintain a good relationship with the customer is to maintain communication with customers such as increase communication through social media such as facebook, whats up group, Instagram and others, and can be done by maintaining loyal customers by providing members cards and discounts for loyal customers. In addition to the customer relationships elements that need to be repaired are key Resources by conducting training and development to employees of both operational and management employees.

Keywords: Business Model Canvas, SWOT Analysis, Strategic Marketing, furniture.

\section{INTRODUCTION}

Furniture business is a quite promising business in Indonesia, Indonesia's furniture products are known to have high competitiveness in the world market. Furniture products in Indonesia has been known by the world market because in addition to the characteristic is also known to be durable because it is made from quality production materials that have good 
quality, this is supported because Indonesia has the raw materials and human resources (SDM) are reliable in making furniture. There has been a shift in the production center of world Furniture. Based on data from CSIL (2016), the contribution of the Asia-Pacific region in the production of world furniture reaches $55 \%$, followed by The European region (14\%), the Americas (26\%), and other regions reached 5\%. Furniture Production Center has shifted to developing countries including Indonesia. This condition differs considerably when compared to 2009 years of data, where developed countries dominate the world's fornitur production to reach $61 \%$ (CSIL, 2009). In addition, furniture is also very attractive by consumers in the country because the furniture is a necessity that can not be separated in daily needs for the community. Besides, the output and added value of Indonesian wood furniture industry has also increased by $113.2 \%$ and $135.4 \%$ respectively, during the 2010 2014 period as shown below:

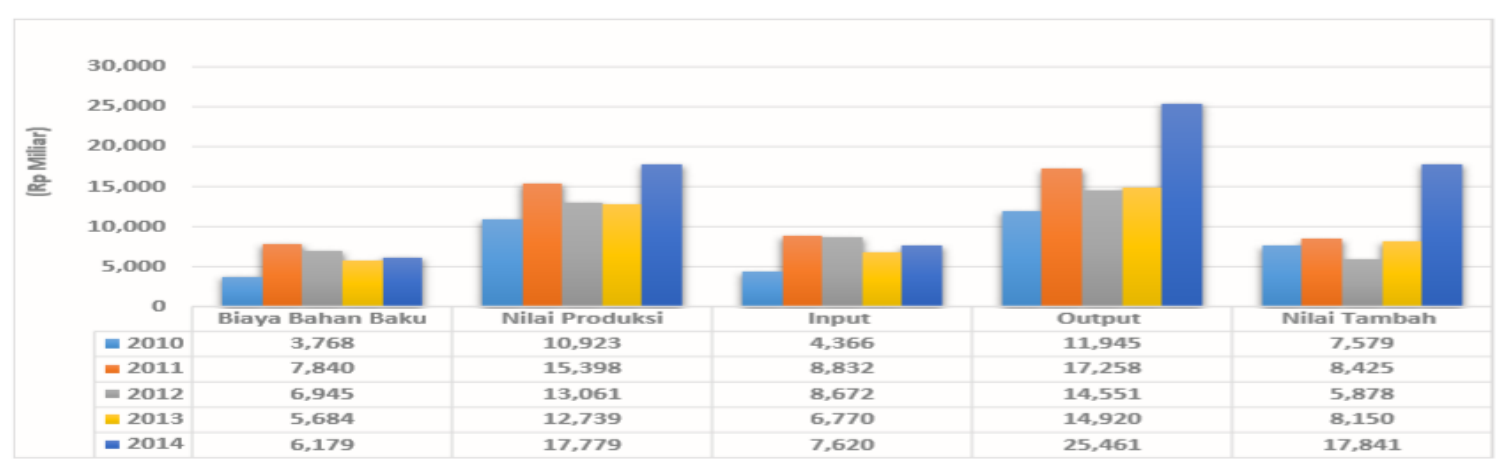

Figure 1 Performnace of the wood furniture industry, 2010 - 2014

Source: Ministry of Industry (2017)

CV. Hakhenbik is a company engaged in furniture (guest chairs, cabinets, beds, dining table ) and school desk) with production material made of solid wood material that has to dourable quatan, and not eaten insects so that has a high selling price, $\mathrm{CV}$. Hakhenbik started its business since the date of 07 March 2011 located in Tangerang, in conducting its business activities CV. Hakhenbik has the vision "to be the best furniture company and create comfort for customers" and have the following mission:

1. Creating products according to customers ' wishes;

2. Improving quality of service in the field of furniture;

3. Expanding job opportunities and striving;

4. Become a trusted partner.

In the field of business CV. Hakhenbik Focus on the production of furniture to meet household needs such as: cabinets, beds, guest chairs, dining tables and other-others, as well as producing the needs of schools such as: tables, chairs, and cabinets for the needs of the school. Currently CV Hakhenbik only has the market around the area of Jabodetabek, this is due to lack of knowledge about business development strategy and do not have a business Canvas Model as to give a impression of walking in place, with this research is expected that the authors can help CV. Hakhenbik in making the Business Canvas Model to realize its expectations, given from the inception of this company until now this business has not 
developed well, in this case of course necessary business strategy and the right business Model and better than competitors other furniture companies.

\section{Identification problem}

Based on the explanation in the introduction above, then identify the problem that will be discussed as follows:

1) Identifying how CV. Hakhenbik business strategy uses the Business Canvas Model (BCM).

2) The internal factors of Strengths and Opportunities, as well as factors of Weakness and Threats in CV. Hakhenbik.

\section{Research objectives}

1) To develop the business using the approach Business Canvas Model CV. Hakhenbik.

2) Formulating the right business strategy for CV. Hakhenbik for company business Development.

3) Design Business Canvas Model company that can be applied and in accordance with the proposed business strategy CV. Hakhenbik.

\section{LITERATURE REVIEW}

\section{Furniture}

Furniture comes from the French word (1520-30 AD) which is fourniture, this word comes from the word furnish which means furniture of the house or room, in other words furniture is an object that is in the house and used by homeowners to lie down, sit or can be used to storing small items or daily necessities such as clothes or cups and others.

\section{Business Model}

According to Ostwerwalder and Pigneur (2010), the business model is a model that illustrates the thought of how an organization creates, delivers and captures the value of a business. The concept of a business model should be simple, relevant, and intuitially easy to understand by not intending to simplify the functioning of a very complex company.

According to the PPM team management (2012:5) business model can be grouped into three kelomok IE business model or method, business model seen from elements, and business model as business strategy.

\section{Business Model Canvas (BMC)}

According to Osterwalder and Pigneur (2012:12) Business Model Canvas (BMC) is the same language to describe visualizing, assessing, and changing business models. Business Model Canvas (BMC) has nine blocks of business activities that have a purpose to map strategies to build a strong business, so that they can win the competition and succeed in the long run. The nine blocks are customer segments, value proposition, customer relationships, channels, revenue stream, key resources, key activities, key partners, cost structure as in Figure 2 


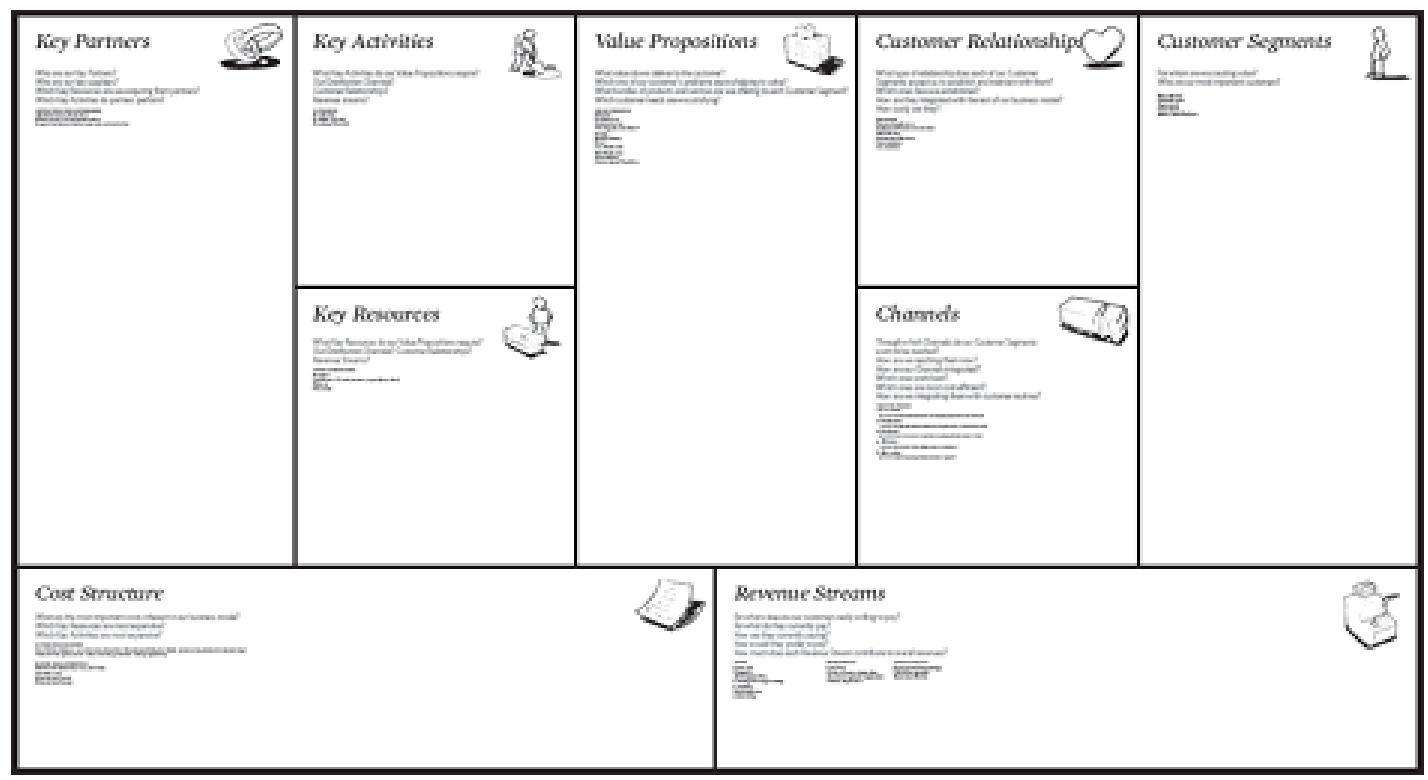

Pictures of 2 Building Blocks Business Model Canvas

(Source: Ostewalder and Pigneur, 2009)

Here's a nine-block model that, if unified, will become one business entity:

1. Customer Segment (CS)

In the concept of customer's business model is placed on the first segment because the company sees the customer segment factor is a very important part, because it serves as an advantage and a determinant for the company in running its business and as a determinant in the sustainability of the company. The Customer segment in Business Model Canvas defines that a group of different people or organisations are targeted to the company to achieve and serve. The Customer segment is divided into several categories; Geography, Demographics and Psychography and others.

2. Value Propostions (VP)

Value Propostions is the product itself from the company both in the form of goods and services produced to meet the needs of the customer segments and is a collection of products or services offered by the company to consumers.

3. Customer Relationship (CR)

Customer relationship or customer relations describe how the company is connecting with its customer segments that are expected by the customers and the puerenterprises. The more customers are tied to a product or service, the more assured the continuity of life and products or services as well as the company.

4. Channels $(\mathrm{CH})$

Once the company has had the products or services offered, then the next step is to deliver the results to the customer. Communication and distribution should go well so that the value of the product will be captured well by the customer. The functions of the channels are as follows:

a. Convey the value propositions offered either in the form of products or services to customers. 
b. Bridging for customers in terms of activities before and after the purchase/use of such products or services.

5. Revenue Stream (RS)

Revenue streams are an overview of the revenue that the company has in each customer segment. When customers get loyal to the company, the company is obliged to think about how the revenue receiving model is profitable for the company and customers. Some models of revenue streams that have been applied include: credit, Cash, CoD, subscription usage fee, licence, rent, leasing, and others.

6. Key Resources (KR)

Key Resources or resources related to the raw materials and channels of suppliers in the production process are used to create and offer value prospositions, reaching the market, maintaining customer relations and earning revenue. Each company has a key resources that are adjusted to the needs and business model. This type of key resources consist of physical, financial, and intellectual.

7. Key Activities (KA)

In block key activities company should describe important things so that operation activities can run smoothly so that achieve success. Key Activities Creating and offering value propositions, maintaining customer relationships, reaching the market and earning revenue according to the business model created by the company.

8. Key Partnership (KP)

The key Partnership Block describes a supplier or supplier network and a colleague who can make a business model work. In the company's key partnership create alliances for the company's business model, lower the risk, and acquire the expected resources. In the implementation there are four types of key partnerships are :

a. Strategy of non-competitor alliances;

b. A strategy of partnership between competitors;

c. Join Venture to develop new business;

d. Cooperation of Buyer-supplier to ensure reliable supply.

9. Cost Structure (CS)

Cost structure describes all costs used to support the implementation of the model business, e.g. creating and delivering value, earning revenue, and maintaining customer relationships. At the preparation of the structure of the fee there are some who must be a concern for companies including;

a. Fixed costs, these costs should always be the same amount incurred even if the product volume changes;

b. Variable costs, the costs that change according to the volume of the product itself;

c. Economic scale, the cost of the company received as a result of increased production amount;

d. Economic reach, the cost profit received by the company due to the magnitude of operational activities. 


\section{SWOT Analysis}

According to Rangkuti (2009:19) A SWOT analysis is a strategic planning method used to evaluate strengths, Weakness, Opportunities, and Threats involved in a project or in business ventures, this involves in determining the target or business venture objectives of the company or project and identifying both the internal and external factors of good and profitable to achieve that goal. This SWOT analysis is based on logic by maximizing ( Strengths) with (Opportunities) the Company's internal factors, minimizing (Weaknesses) with threats (Threats) the company's external factors, the process in strategic decision making that is always related to the development of the company's mission, corporate objectives, corporate strategy, and corporate policy. Strategy planners should analyse factors such as strengths, weaknesses (Weaknesses), Opportunities (Opportunities), and threats (Threats), under existing conditions. This is called the situation analysis.

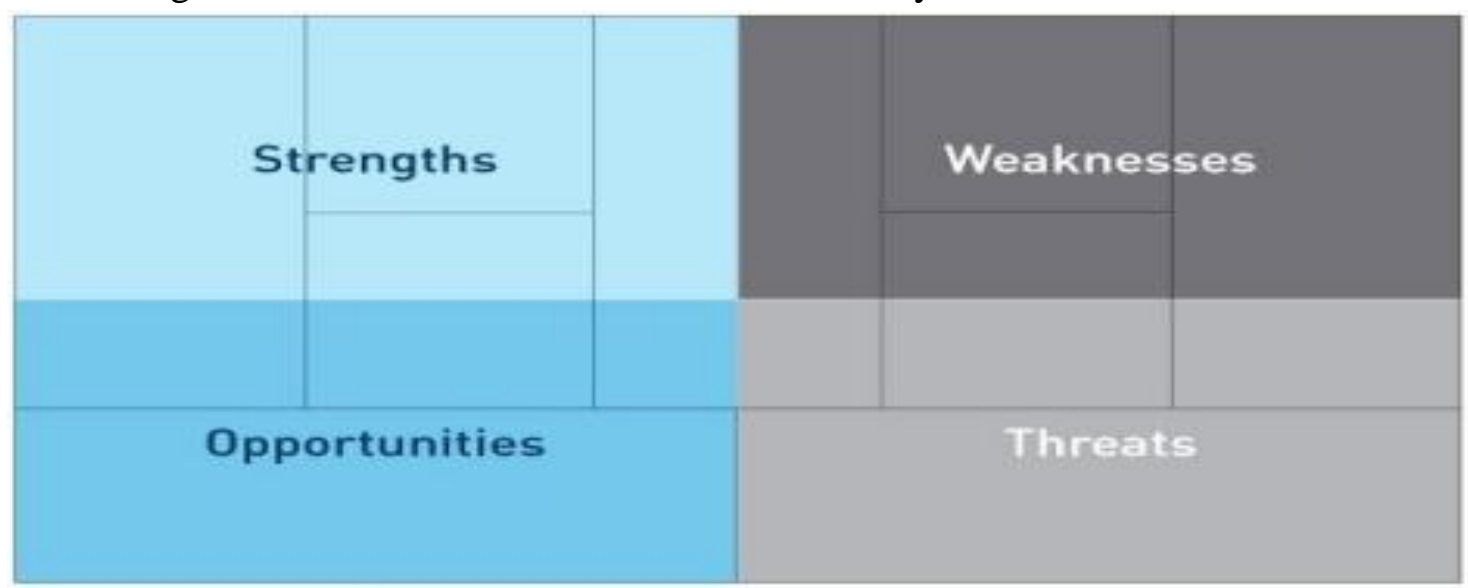

Figure 3 Business Model Generation, Alexander osterwalder and Yves pigneur, 2010

\section{RESEARCH METHODS}

In this research authors use qualitative descriptive method that is by using Business Model Canvas Business Model (BMC), then evaluated using a SWOT analysis in each block Business Model Canvas (BMC) in CV. Hakhenbik. According to Suprapto (2013) Descriptive research is a study of the status, attitudes, opinions of individual groups, device conditions and procedures, of thought or events in order to make a description or a systematic depiction and analytics that can be used to solve a problem at present.

The conceptual definition in this study is about Business Model Canvas (BMC) and SWOT Analysis on Business Model Canvas (BMC). The type of data used is qualitative data. According to Moleong (2014) qualitative data is data that is not stated in the form of numbers or numbers but in the form of sentences that describe an event or activity. In this study, using two data, primary data and secondary data. Primary data obtained from interviews with informants who were sampled in the study. Secondary data according to Sarwono (2006) is data that has been available and can be obtained by researchers by reading, listening and viewing. In its implementation, researchers took information related to this study from book sources, archives and official documents from CV. Hakhenbik. 


\section{FINDINGS AND DISCUSSION}

\section{Results of the discussion}

CV. Hakhenbik is one of the MKM in the District Tangerang engaged in the field of furniture. The company was established on 07 March 2011 which is located in Jalan Barang Baru number 01 Kosambi District of Tangerang Regency, in this study authors use Business Model Canvas which is based on nine elements, namely: Customer segments, value propositions, channels, customer relationships, revenue streams, key resources, key activities, key partnerships, and cost structure.

\section{Business Model Canvas \\ Customer Segments}

Customer segments targeted by CV. Hakhenbik are for schools and residential because of the place of CV. Hakhenbik adjacent to schools and housing, other than that the owner of CV. Hakhenbik retired teachers so many relationships with schools-schools are both public and private schools, besides the large number of housing provides the opportunity to be able to market the products such as household needs such as cabinets, guest chairs, dining tables and others. According to Ostewlder and Pigneur (2010), customer segment CV. Hakhenbik is kind of segmented, that is this type of directing to serve customers who classified again based on customer needs and problems

\section{Value Propositions}

A value that satisfies the needs of customers who have never been fulfilled because there are no similar or similar offerings before. CV. Hakhenbik offers furniture products different from the manufacturer that is a kind of product offered from the good quality of wood teak wood from Jepara and mahogany wood with good quality for chair and school table, besides in the coloring CV. Hakhenbik using Duko method and melamik so that the quality of staining will produce good quality. In the performance element CV. Hakhenbik According to information received by the author through the current informant provide polite and friendly service, the service is given on time at the time that has been agreed by the customer, the product is already good and satisfying customer. In the customization element which means the value received by the special needs of the customer, Informant gives information that $\mathrm{CV}$. Hakhenbik has a special ability to serve in accordance with the request outside the company catalogue and product results according to the wishes of the customer. For the price element, according to the informant that the author received that $\mathrm{CV}$. Hakhenbik has a relatively cheaper price compared to other competitors. On the accessibility element CV. Hakhenbik provide free goods delivery service for the area of Jakarta, and Tangerang, and CV. Hakhenbik provide convenience for customers who will order. Later in the vonvenience element or usability CV. Hakhenbik has a place of business located on the roadside and has a large building and parking area available, so make customer safe and comfortable visit CV. Hakhenbik.

\section{Channels}

In the Channels element CV. Hakhenbik implemented a strategy by joining the exhibition and Bazar held by the government of Tangerang District and the Society of the 
Tangerang district, besides, CV. Hakhenbik markets its products through social media such as whats up, Facebook, Instagram and others.

\section{Customer Relationships}

$\mathrm{CV}$. Hakhenbik has a strategy of personal approach to maintain good relationship with the old customer by providing the best service by visiting the customers by inviting to eat near the beach with the customer and give souvenirs. For customer acquisition that means continuous looking for new customers the strategy used CV. Hakhenbik has a strategy to create a network with the principals and networks Arisan as a strategy attracting interest to new customers. The implementation Customer Relationship category in CV. Hakhenbik is personal assistance, which is customer can communicate directly not only with online media but can directly communicate with employees of CV. Hakhenbik from the process of ordering, product manufacturing process (order model, the desired product color and until the payment process).

\section{Revenue Stream}

Revenue from CV. Hakhenbik derived from project-projects from the government and private with the purchase of large-scale products, in addition to the income of CV. Hakhenbik derived from direct or offline sales and online sales of products sold, in addition to the CV.

\section{Key Resources}

Assets owned by CV. Hakhenbik is in the form of equipment used to produce raw materials such as wood cutting machines, wood lathes, wood cutting grinders, compressors to paint wood and other equipment. Besides that CV. Hakhenbik has assets that are owned or not leased which are used to produce products until they are ready to be distributed to customers. Human assets owned by CV. Hakhenbik numbered 5 people, but did not rule out the possibility of adding new employees who had the skills to make furniture, desks and chairs for schools. For financial assets besides sourced from the owner, CV Hakhenbik received a loan from the Cooperative UMKM Tangerang Regency.

\section{Key Activities}

The next segment is the key activites category on the CV. Hakhenbik is included in the category of production, meaning that the activities carried out by CV. Hakhenbik deals with making and delivering good quality products. CV production activities. Hakhenbik consists of several parts including: purchase of wood raw materials, processing of raw materials, coloring and delivery.

\section{Key Partnerships}

Partnership motivation CV. Hakhenbik is an optimization and economy of scale, a buyer-supplier relationship designed to optimize the allocation of resources and CV activities. Hakhenbik uses two suppliers to supply raw materials needed first in Jepara, and second in East Jakarta, this is done to mitigate if there are orders that require time quickly the raw materials will be ordered from the city of East Jakarta. For maintaining good relations with partners CV. Hakhenbik will order raw materials from the two suppliers and will not move around, then try to pay raw materials as much as possible to be paid on time. Types of partnerships on the CV. Hakhenbik is a buyer-supplier relationship to assure reliable supplies, which means a buyer-supplier relationship to guarantee reliable supplies. Then the value 
offered by CV. Hakhenbik, namely the quality of products with raw materials from the best quality wood, is very dependent on the supplier, if the quality of the raw materials offered by the supplier is good, the products produced will be good.

\section{Cost Structure}

According to data obtained from informants that the cost structure in the CV. Hakhenbik focuses on cost-driven which means that CV. Hakhenbik focuses on minimizing costs in order to create and maintain the possibility of the leanest cost structures, offering inexpensive value propositions and extensive outsourcing so that consumers get low prices. $\mathrm{CV}$ expenses. Hakhenbik consists of two, namely fixed costs and variable costs. Fixed costs consist of employee salary costs, electricity costs, telephone calls, while variable costs consist of raw materials, transportation costs for product delivery to consumers.

\section{SWOT Analysis}

\section{Customer Segments}

Strengths in customer relationships are indicated by high customer loyalty, namely customers from around the area of CV production. Hakhenbik and schools that have a closeness with the owner of the CV. Hakhenbik. The opportunities are the most likely CV. Hakhenbik has a new customer outside the production area of CV. Hakhenbik. Threats is not closing the possibility of customers moving to other furniture companies.

\section{Value Proporstions}

Strengths in the elements of value propositions are the values offered according to what is needed by consumers. The company's value has a strong impact on expanding consumer networks, product integration with good service and the reputation of $\mathrm{CV}$. Hakhenbik is good. Weakness is CV. Hakhenbik does not have an advantage in the brand. Opportunities are service improvements to increase revenue. Threats is that competitors have catalogs with the latest product models.

\section{Channels}

The strengths in this element is the CV. Hakhenbik has its own place of business and is located on the side of the road with access to the location is very easy and has a large parking area. Weaknesses namely the shipping location is not extensive only in Tangerang and Jakarta. Its opportunities are to open new branches to reach customers outside the Tangerang and Jakarta areas.

\section{Customer Relationships}

Strengths on customer relationships CV. Hakhenbik with customers is very good. Weaknesses are CV. Hakhenbik doesn't have a brand yet so it doesn't have a positive impression for customers. Threats on the CV. Hakhenbik in this element towards consumers can be seriously threatened.

\section{Revenue Streams}

Strengths in customer revenue streams are relatively appropriate pricing and other sources of income from wood waste and sawdust. Weaknesses for managing revenue have not been good. Opportunities CV. Hakhenbik can get additional income by adding revenue 
by adding other income streams and CV. Hakhenbik can raise prices at any time. Threats depend on one income stream.

\section{Key Resources}

Strengths on key resources, namely the ease of getting resources. Weaknesses are CV. Hakhenbik main resources are easily obtained by competitors and human resources must be developed. Opportunities can choose and use cheaper resources with good quality. Threats namely raw materials have limitations so that it impacts on product quality.

\section{Key Activities}

Strengths of key activities that can run an effective and efficient business. Weakness is the main activity can be imitated by competitors. The opportunities are CV. Hakhenbik can standardize key activities. Threats is the threat of competitors who have better key activities.

\section{Key Partners}

Strengths on key partners, namely the relationship of CV. Hakhenbik is very good. Weaknesses are less extensive partner networks. Opportunities, networks owned by partners, can help CV. Hakhenbik gets wider consumers. Threats, that is, suppliers can collaborate with competitors.

\section{Cost Structure}

Strengths on the cost structure is the cost of operations in accordance with company needs. Weakness is the company's monthly cost is difficult to predict and there is still usage that cannot be controlled.

\section{CONCLUSION AND SUGESTION \\ Conclusion}

Based on the results of analysis AND discussion on the business model on CV. Hakhenbik by using the Business Model Canvas, maka The conclusion on penelitian This research is as follows:

Embodies the most powerful in Business Model Canvas is key Partnership because of CV. Hakhenbik with a Partner Its business very good thing. Next is the value propositions because of the value offered by $\mathrm{CV}$. Hakhenbik has been In accordance with a The needs and wishes of his customer As for element The element is still lacking is customer relationships because it has a considerable threat from competitors that can lead to customer move and next is key Resources because the resources owned is still less good as human resources do not have a standard in creating and marketing products.

From the research results can be created business model Canvas that can be used to develop the business model for CV. Hakhenbik can develop Well, the Business Model of the Canvas is as follows: 


\begin{tabular}{|c|c|c|c|c|c|}
\hline Key Partners & Key Activities & \multicolumn{2}{|c|}{ Value Proposition } & $\begin{array}{c}\text { Customer } \\
\text { Relationships }\end{array}$ & Customer Segments \\
\hline \multirow[t]{2}{*}{$\begin{array}{l}\text { Collaborate with } \\
\text { other partners } \\
\text { such as banks, } \\
\text { cooperative } \\
\text { UMKM }\end{array}$} & $\begin{array}{l}\text {-Social Media } \\
\text { marketing methods } \\
\text { that include } \\
\text { uploading photos } \\
\text { of CV. } \\
\text { Hakhenbik's } \\
\text { products- } \\
\text { informing the } \\
\text { current products }\end{array}$ & \multirow{2}{*}{\multicolumn{2}{|c|}{$\begin{array}{l}\text { - Brand elements: } \\
\text { a unique, attractive, } \\
\text { and easy-to- } \\
\text { remember product } \\
\text { name } \\
\text {-Create catalogue } \\
\text { designs for } \\
\text { attractive products } \\
\text {-maximize timely } \\
\text { service even when } \\
\text { booking is crowded } \\
\text {-make a design for } \\
\text { new dwellers }\end{array}$}} & $\begin{array}{l}\text {-Increase } \\
\text { communication } \\
\text { media with } \\
\text { customer-create } \\
\text { member card for } \\
\text { customer and give } \\
\text { discount for loyal } \\
\text { customer } \\
\text {-promotion through } \\
\text { social media such as: } \\
\text { group whats up, } \\
\text { Facebook, Instagram } \\
\text { and others }\end{array}$ & \multirow[t]{2}{*}{$\begin{array}{l}\text { Focus on } \\
\text { operational workers }\end{array}$} \\
\hline & $\begin{array}{l}\text { Key Resource } \\
\text {-Employee } \\
\text { training-making } \\
\text { patents } \\
\text {-addition of new } \\
\text { supplier } \\
\text {-human resources } \\
\text { enhancement for } \\
\text { marketing } \\
\end{array}$ & & & $\begin{array}{l}\text { Channels } \\
\text {-Collaborate with } \\
\text { many developers and } \\
\text { schools. } \\
\text {-Opening new } \\
\text { branches for business } \\
\text { development }\end{array}$ & \\
\hline \multicolumn{3}{|c|}{$\begin{array}{l}\text { Cost Stucture } \\
\text {-Focus structure Fee: cost-driven } \\
\text {-Fixed cost : Employee salary, } \\
\text { electricity cost, and telephone } \\
\text {-Variable cost: Raw material cost, } \\
\text { postage product } \\
\text {-Potential costs are the cost of raw materials }\end{array}$} & \multicolumn{3}{|c|}{$\begin{array}{l}\text { Revenue Stream } \\
\text {-Source of income: Product sales } \\
\text { - Type revenue stream: Payment earned from one-time } \\
\text { payment }\end{array}$} \\
\hline
\end{tabular}

Figure 4 Business Model Canvas CV. Hakhenbik

\section{Suggestions}

\section{Customer Segments}

$\mathrm{CV}$. Hakhenbik can focus on perational employees, especially employees who make products by doing training and coaching and pay attention to the old days of employees allowance.

\section{Value Propositions}

In the brand element it is suggested CV. Hakhenbik creates products with unique, attractive names that are easily remembered by its customers. Besides that, CV. Hakhenbik is advised to create a new product catalog that has a unique and attractive design to be seen by customers, as well as maximizing friendly service so that it attracts customers, and creates products in the form of packages for new housing residents and provide discount discounts to new customers.

\section{Channels}

In CV Hakhenbik channels elements. Hakhenbik recommended to establish cooperation with the developer of property, and schools to improve the market and open new branches for $\mathrm{CV}$. Hakhenbik can thrive in running his business. 


\section{Customer Relationships}

To maintain customer relationships CV. Hakhenbik is advised to make a lot of communication with customers to make member cards for their customers and discounts to loyal customers and make promos via social media via Facebook, instagran, and others.

Revenue Stream To increase the income of CV. Hakhenbik can make new innovations in producing products, utilizing wood waste to be sold as firewood, and fertilizer for plants.

\section{Key Resources}

In this element CV. Hakhenbik can make improvements by providing training to employees, both operational employees and managerial employees. To protect copyright in the manufacture of products it is recommended to CV. Hakhenbik makes patents so that every product cannot be copied by competitors. So that raw materials are not lacking it is advisable to add new suppliers so that production activities can run well without obstacles.

\section{Key Activities}

In the key activities element in order to increase sales of CV. Hakhenbik is advised to carry out marketing methods through social media by uploading products issued by $\mathrm{CV}$. Hakhenbik, and inform the products that are being promo.

\section{Key Partnerships}

In the element of key partnerships to expand customer reach, CV. Hakhenbik can collaborate with partners such as banks, and cooperatives of the Tangerang Regency Regional Government.

\section{Cost Structure}

In cost structure elements that are difficult to control costs are telephone costs and electricity costs, for that in reducing telephone costs it is advisable to disconnect the telephone lines and replace them with mobile phones and computer devices to more easily control their use, and to reduce electricity costs can be made Standard Operating Procedure (SOP) for the use of AC, electricity and water. Another way is to replace the low wattage AC and lights with the use of LED lights to be more efficient.

Based on SWOT analysis, CV. Hakhenbik is advised to improve on the elements of customer relationships because this is an important factor in running a business. It is maintaining good relations with customers. If the customer decreases, then whisper will be difficult to develop, one way to maintain good relationships with customers is to maintain communication with customers such as increasing communication through social media such as Facebook, whats up groups, Instagram and others, and can be done by keep loyal customers by giving member cards and discounts for loyal customers. In addition to the elements of customer relationships that need to be improved are key resources by conducting training and development for employees both operational and management employees.

\section{REFERENCE}

Ali, H., Butarbutar, B. (2019). Analisis SWOT Dalam Menentukan Strategi Pemasaran Produk Jus Bawang Putih Dr Juice 5 In 1 (Studi Kasus: CV. Dewi Rejeki Jakarta). Jurnal Ilmiah Manajemen. 
Ali, Hapzi. 2020. Modul Strategic Management Program Studi Magister Management. UMB Jakarta.

Osterwalder, A.,Pigneur, Y. (2010). Business model generation: a handbook for visionaries, game changers, and challengers. New Jersey: John Wiley \& Sons, Inc.

Meleongh, L. J. (2014). Metodologi Penelitian Kualitatif. Bandung: Remaja Rosdakarya.

Suprapto. (2013). Metodologi penelitian ilmu Pendidikan dan ilmu-ilmu pengetahuan sosial: penelitian kuantitatif dan kualitatif dilengkapi dengan keknik pengolahan data dan table statistic. CAPS (Center for Academic Publishing Service).

Rangkuti, F. (1998). Analisis SWOT Teknik Membedah Kasus Bisnis. Jakarta: PT Gramedia.

Kamaluddin, I. (2020). Analisis SWOT untuk merumuskan strategi bersaing pada PT. Menara Angkasa Semesta Cabang Sentani. Jurnal Ilmu Manajemen Terapan, 1(4), 342-354. https://doi.org/10.31933/jimt.v1i4.183. 